\title{
PENGARUH KUALITAS WEBSITE, KUALITAS PELAYANAN, DAN KEPERCAYAAN PELANGGAN TERHADAP MINAT BELI PELANGGAN DI SITUS BELANJA ONLINE BUKALAPAK
}

\author{
Ade Indra Permana \\ Fakultas Ekonomi dan Bisnis \\ Universitas Islam Syekh Yusuf Tangerang \\ aipermana@unis.ac.id \\ https://doi.org/10.33592/jeb.v25i2.422
}

\begin{abstract}
This study examines the influence of website quality, service quality, and customer trust on customer buying interest on Bukalapak online shopping sites. The research was conducted because in the millennial era, business competition on online shopping sites increased so that the need for online shopping site companies Bukalapak, continued to improve the quality of the website / application, service quality and increase the trust of customers, with the hope that Bukalapak online shopping sites would dominate the market share or become market leader. This study aims to determine the effect of website quality, service quality, and customer confidence in buying interest on Bukalapak online shopping sites. The quantitative research method is by looking for causal relationships. The study was conducted in the city of Tangerang, with a total sample of 100 respondents, conducted on customers who had shopped on the Bukalapak online site. The research instrument was in the form of a questionnaire to get respondents' empirical data. From the results of the study showed the influence of website quality variables, service quality, and customer confidence in customer buying interest of 0.499 or $49.9 \%$, while the rest are residual variables. The results of the analysis of website quality, service quality, and customer trust, together affect the customer's buying interest. Website quality has a positive effect on customer buying interest. Service Quality has a positive effect on customer buying interest. Customer trust shows that customer trust does not have a positive effect on customer buying interest.
\end{abstract}

Keywords: quality, service, trust, shopping, online

\begin{abstract}
Abstrak
Penelitian ini meneliti pengaruh kualitas website, kualitas pelayanan, dan kepercayaan pelanggan terhadap minat beli pelanggan di situs belanja online Bukalapak. Penelitian dilakukan karena di era milenial, persaingan bisnis pada situs belanja online semakin meningkat sehingga perlunya perusahaan situs belanja online Bukalapak, terus melakukan perbaikan kualitas websitel aplikasi, kualitas pelayanan dan meningkatkan kepercayaan dari pelanggan, dengan harapan situs belanja online Bukalapak menguasai pangsa pasar atau menjadi market leader. Penelitian ini bertujuan untuk mengetahui pengaruh kualitas website, kualitas pelayanan, dan kepercayaan pelanggan terhadap minat beli di situs belanja online Bukalapak. Metode penelitian kuantitatif yaitu dengan mencari hubungan secara kausal. Penelitian dilakukan di Kota Tangerang, dengan jumlah mengambil sampel 100 orang responden, dilakukan terhadap pelanggan yang pernah belanja di situs online Bukalapak. Instrumen penelitian berupa kuesioner untuk mendapatkan data empiris responden. Dari hasil penelitian menunjukkan pengaruh variabel kualitas website, kualitas pelayanan, dan kepercayaan pelanggan terhadap minat beli pelanggan sebesar 0,499 atau 49,9\%, sedang sisanya merupakan variabel residu. Hasil analisis kualitas website, kualitas pelayanan, dan kepercayaan pelanggan, secara bersama-sama berpengaruh terhadap minat beli pelanggan. Kualitas website berpengaruh positif terhadap minat beli pelanggan. Kualitas Pelayanan berpengaruh positif terhadap minat beli pelanggan. Kepercayaan pelanggan menunjukkan bahwa kepercayaan pelanggan tidak berpengaruh positif terhadap minat beli pelanggan.
\end{abstract}

Kata kunci: kualitas, pelayanan, kepercayaan, belanja, online 


\section{A. Pendahuluan}

Di era digital saat ini, masyarakat Indonesia semakin menunjukkan minat yang semakin tinggi untuk memilih online shopping dalam memenuhi kebutuhan dan keinginannya. Hal ini dipengaruhi oleh pengguna internet dan adanya infrastruktur digital yang terus berkembang, sehingga masyarakat sudah mulai mengenal dan terbiasa untuk melakukan belanja melalui situs belanja online. Hal ini pun disambut baik oleh para pendiri bisnis situs belanja online, sehingga bermunculan toko-toko online, seperti Lazada, Bukalapak, OLX, Tokopedia, Pikub.com, dan lain-lain (Laily, 2019).

Perubahan dan teknologi yang terus berkembang pada industri 4.0 dari waktu ke waktu semakin cepat, tak terduga, komplek dan membingungkan/ ambigu. Perubahan dan perkembangan teknologi ini menbawa pengaruh besar pada kegiatan bisnis dan perdangangan. Bisnis perdagangan ini, disebut dengan perdagangan yang dilakukan secara elektronik (e-commerce). E-commerce itu sendiri merupakan kemudahan gaya hidup untuk melakukan transaksi bisnis antara penjual dan pembeli yang dilakukan secara online sehingga dapat dilakukan dimanapun berada (Hidayat, 2008).
Seperti yang terjadi pada situs belanja online Bukalapak. Situs ini memiliki sebuah website maupun aplikasi yang dapat didownload oleh para pelanggan atau pengguna, sehingga mereka dapat berbelanja online dengan mudah tanpa harus keluar rumah dengan memanfaatkan smartphonel gadget yang ada. Berikut sebuah survei yang dilakukan oleh Asosiasi Penyelenggara jasa Internet Indonesia pada tahun 2018 perihal Website E-Commerce yang dikenal oleh masyarakat Indonesia:

Tabel 1. Website E-commerce yang dikenal masyarakat.

\begin{tabular}{|c|c|}
\hline Website & Presentasi \\
\hline Shopee & $11,2 \%$ \\
\hline Bukalapak & $8,4 \%$ \\
\hline Lazada & $6,7 \%$ \\
\hline Tokopedia & $4,3 \%$ \\
\hline Traveloka & $2,3 \%$ \\
\hline OLX & $0,6 \%$ \\
\hline Amazon & $0,1 \%$ \\
\hline Blibli & $0,1 \%$ \\
\hline Alibaba & $0,1 \%$ \\
\hline
\end{tabular}

Sumber : Asosiasi Penyelenggara Jasa Internet Indonesia, 2018

Pada tabel data di atas menunjukkan pada tahun 2018, W\&S Group melakukan sebuah riset untuk mengetahui situs belanja online yang dikenal oleh masyarakat yang digunakan untuk membeli produk baik barang maupun jasa. Secara online, Shopee menduduki urutan pertama dengan 11,2\% dan Bukalapak pada urutan kedua dengan sebesar $8,4 \%$, 
Lazada pada urutan ketiga sebesar 6,7\%, dan urutan keempat yaitu Tokopedia sebesar 4,3\%, urutan kelima Traveloka sebesar 2,3\%, dan lain-lain sebagaimana data di atas. Masih banyaknya masyarakat yang kurang percaya dengan online shopping dari data menunjukkan 53,4\% masyarakat tidak berkunjung ke website online shopping (Roy Franedya, 2019).

Faktor dari kualitas pelayanan, juga dapat menarik calon pembeli. Lemahnya pelayanan yang diberikan Bukalapak seperti konfirmasi pembayaran yang cukup lama, tidak adanya fasilitas pelayanan COD akan membuat pembeli merasa khawatir sehingga mempengaruhi keputusan pembelian.

Sebagian orang berpendapat, bahwa online shopping ini lebih efektif dan efisien, karena dapat membantu masalah dalam berbelanja. Namun dari keefektifan dan keefisienan ini, tentunya ada resiko yang timbul sehingga menjadi kekhawatiran bagi pelanggan. Menurut Kementrian Komunikasi dan Informatika, 2013, bahwa yang dimaksud dengan resiko disini dengan terkaitnya kejadian masalah penipuan, keamanan, dan muncul ketidakpuasan bagi pelanggan. Hal ini perlu adanya interaksi antara penjual dan pembeli, karena dari interaksi atau komunikasi akan menimbulkan reaksi kepercayaan terhadap pelanggan. Yang dimaksud dengan kepercayaan pelanggan ialah sebuah pengetahuan bagi pelanggan bahwa produk itu mempuyai kegunaan dan manfaat bagi pelanggan tersebut.

Dari data Asosiasi Penyelenggara Jasa Internet Indonesia, terlihat perbandingan dari penguna internet dan online shopping ini. Sebagian pengguna online shopping menganggap, bahwa transaksi jual beli online akan memakan waktu yang lama serta menimbulkan keraguan dari ketidaksesuaian antara produk yang ditampilkan di gambar sebagai contoh dan produk yang akan diterima.

Tabel 2. Alasan tidak melakukan jual beli secara online shopping

\begin{tabular}{|l|c|}
\hline \multicolumn{2}{|c|}{ secara online shopping } \\
\hline Alasan & Presentase \\
\hline Tidak tahu & $24,3 \%$ \\
\hline Tidak jawab & $3,7 \%$ \\
\hline Lainnya & $18,8 \%$ \\
\hline $\begin{array}{l}\text { Lebih suka beli langsung } \\
\text { karena barang langsung } \\
\text { dapat }\end{array}$ & $12,2 \%$ \\
\hline $\begin{array}{l}\text { Belum bisa menggunakan } \\
\text { website atau aplikasi }\end{array}$ & $9,5 \%$ \\
\hline $\begin{array}{l}\text { Khawatir barang tidak } \\
\text { sampai }\end{array}$ & $9,0 \%$ \\
\hline $\begin{array}{l}\text { Khawatir barang tidak } \\
\text { sesuai }\end{array}$ & $4,5 \%$ \\
\hline $\begin{array}{l}\text { Rumit karena harus transfer } \\
\text { Takut barang tidak bisa } \\
\text { dikembalikan kalau tidak } \\
\text { sesuai }\end{array}$ & $3,4 \%$ \\
\hline Waktu pengiriman lama \\
$\begin{array}{l}\text { Sumber: Asosiasi Penyelenggara Jasa Internet } \\
\text { Indonesia, 2018. }\end{array}$ \\
\hline
\end{tabular}


Dari gambar data di atas menunjukkan, bahwa ada beberapa alasan masyarakat tidak pernah melakukan belanja produk baik barang ataupun jasa secara online, yaitu:

1. Diurutan pertama, lebih suka berbelanja secara langsung, dengan besaran prosentasi 18,8\%. Karena dengan berbelanja secara langsung pembeli dapat memegang, memilih, dan melihat barang tersebut bagus atau tidaknya sehingga memberi keyakinan tersendiri buat pembeli.

2. Diurutan kedua, prosentasi sebesar $12,2 \%$ beralasan belum bisa menggunakan website atau aplikasi ini. Pelanggan seperti ini lebih banyak dari kalangan masyarakat yang berumur sudah lanjut usia, karena merasa kurang paham akan dalam menjalankan website atau aplikasi.

3. Diurutan ketiga, sebesar $9,5 \%$ beralasan pelanggan merasa khawatir barang yang dibeli sampai dalam waktu yang cukup lama atau lebih lama. Hal ini alamiah bagi seorang pelanggan yang merasakan kekhawatiran tersebut karena kita tidak tahu kondisi barang tersebut seperti apa, ketika sampai di tangan pelanggan sesuai dengan harapan, atau banyak kerusakan yang tidak diharapkan pelanggan.
4. Diurutan keempat, 9,0\% pelanggan merasa khawatir barang tidak sampai. Alasan ini cukup logis karena banyaknya barang yang kita beli ada saja barang yang tidak sesuai ekspektasi pelanggan.

5. Diurutan kelima, $4,5 \%$ pelanggan beralasan rumit karena harus transfer. Alasan ini banyak terjadi pada masyarakat terutama di daerah yang infrastruktur digital/ teknologi yang belum masuk/ terbatas, misalnya karena tidak setiap orang memiliki ATM, yang dan masyarakat seperti ini hanya bisa atau merasa nyaman bila pembayaran melalui cash.

6. Diurutan keenam, sebesar 3,4\% beralasan takut barang tidak bisa dikembalikan kalau tidak sesuai. Hal ini dapat dialami ketika kita membeli suatu barang, dan barang tersebut rusak saat sampai di tujuan, ketika dicek oleh pelanggan, ketakutan akan barang tidak bisa dikembalikan dari sipenjual, karena ketika kita complain ada saja penjual yang cuek akan complain yang dilakukan oleh pelanggan.

7. Diurutan ketujuh, $0,7 \%$ beralasan waktu pengiriman yang lama. Hal ini lumrah dalam hal ekspedisi pengiriman, ada saja pengiriman barang yang sangat lama karena ketika diantar ke alamat pelanggan tetapi kurir pengiriman 
kurang memahami daerahnya, ini bisa menjadi kendala yang serius, karena ketika kurir ini sudah tidak tau alamat pelanggan, maka barang akan disimpan lagi di gudang, ini yang menyebabkan pengiriman yang sangat lama.

Faktor kepercayaan adalah hal yang utama yang mempengaruhi bagaimana belanja di situs online, tanpa ada kepercayan dari pelanggan, bisnis apapun tidak akan berjalan dengan lancar. Kepercayaan dari sang pembeli bergantung pada informasi yang disampaikan penjual di situs website (Ghani, 2018)

Minat beli pelanggan diartikan sebuah perilaku pelanggan di mana pelanggan mempunyai keinginan untuk memilih dan membeli suatu produk, berdasarkan pengalaman, penggunaan dan konsumsi suatu produk (Satria, 2017). Faktor-fakor yang mempengaruhi minat membeli berhubungan dengan perasaan dan emosi, bila seseorang merasa senang dan puas dalam membeli barang atau jasa, maka akan memperkuat minat untuk membeli, dan ketidakpuasan biasanya menghilangkan minat beli (Satria, 2017).

\section{Kualitas Website}

Website merupakan kumpulan informasi baik berupa teks, naskah, gambar diam atau gerak, animasi, suara, dan atau gabungan dari kesemuanya, yang bersifat statis maupun dinamis yang membentuk satu rangkaian sistem yang saling berkaitan, dimana masing-masing dihubungkan dengan link halaman (Bekti, 2015).

Dengan website akan memudahkan pelanggan di dalam mencari informasi produk perusahaan. Dengan informasiinformasi produk yang dapat dijumpai di situs website, akan memudahkan pelanggan mendapat kesimpulan tentang fitur dan benefit suatu produk, sehingga dapat menarik kebutuhan dan keinginan dari produk yang ditawarkan perusahaan (Jackson, 2009).

Dalam studi WebVisible / Nielson, 82 persen responden mengatakan bahwa mereka telah menggunakan internet untuk menemukan bisnis lokal; 80 persen mengatakan mereka telah meneliti produk atau layanan online sebelum membeli. Jadi bisnis dengan situs online menjadi marak karena memudahkan untuk mendapatkan informasi produk (Fox, 2010).

Kualitas website adalah suatu taktik atau metode pengukuran berdasar atas pendapat orang yang menggunakannya. Kualitas website ini juga dapat dilihat dari besarnya kontribusi terhadap kegunaan para pelanggan. Hasil penelitian Gregg dan Walczak, menyatakan bahwa kualitas situs web (webqual) dapat meningkatkan penjualan, dan intensitas transaksi 
penjualan sebesar 12\% (Gregg \& Walczak, 2010). Kualitas website, berpengaruh terhadap kepercayaan, dan kepercayaan berpengaruh terhadap loyalitas pelanggan belanja online.

Para peneliti membagi kriteria kualitas website menjadi lima dimensi, yaitu (Kim \& Niehm, 2009):

1) Keamanan, yang dapat memberikan jaminan keamanan akan privasi, dan kepercayaan.

2) Kenyamanan, memberikan daya tarik emosional, desain yang kreatif, inovatif, serta menarik secara visual.

3) Informasi, memberikan informasi yang akurat, bermanfaat, kualitas secara isi dan relevan terhadap maksud utama.

4) Kemudahan, Informasi yang ada memberikan kemudahan untuk dipahami, mudah dioperasikan dan diproses serta memiliki kecepatan dalam proses.

5) Kualitas pelayanan, memiliki pelayanan yang lengkap secara online dalam melayani pelanggan.

\section{Kualitas Pelayanan}

Kualitas pelayanan terhadap suatu barang dan jasa akan sangat bersifat dinamis tergantung kepada ekspektasi dari manusia, terdapat lima dimensi yang dapat mempengaruhi kualitas pelayanan (Arie Prayoga, 2018) :
1) Tangible, kualitas yang secara langsung dapat dirasakan masyarakat baik dari sisi tampilan maupun perlakuan yang dirasakan dalam pelayanan

2) Realibility (kehandalan), yaitu pelayanan yang dirasakan oleh konsumen sesuai dengan janji yang sebelumnya disampaikan, yang merupakan suatu pelayanan minimal

3) Responsiveness (daya tanggap), yaitu perilaku tanggap di dalam melayani.

4) Assurance (jaminan), yaitu suatu jaminan akan kualitas dan keamanan.

5) Empathy (empati), yaitu sikap yang sangat memperhatikan pelanggan, peduli terhadap kepentingan pelanggan yang dilakukan secara individual.

\section{Kepercayaan Pelanggan}

Belanja di situs online merupakan dampak dari keterbukaan teknologi yang bertumbuh pesat di era sekarang ini. Ketika awal-awal muncul adanya situs belanja online, banyak orang sebagai calon pelanggan merasa tidak yakin untuk berbelanja di situs online, namun saat ini kebanyakan orang atau pelanggan sudah mulai percaya bahkan lebih bergantung terhadap informasi-informasi yang ada di dalam website serta terhadap kesaksian atau testimoni para pelanggan yang telah merasakan pelayanan pada situs belanja online, meski pelanggan belum melihat 
secara fisik produk yang ditawarkan dalam situs belanja online (Büttner \& Göritz, 2008).

Kepercayaan (trust) merupakan salah satu faktor kunci yang menjadikan para langganan melakukan pembelian khususnya pada saat dimana seseorang melakukan pembelian secara online dengan pertimbangan resiko yang kecil. Tanpa adanya kepercayaan dari pelanggan, maka transaksi pada situs belanja online akan lebih sulit terjadi (Gutavsson, 2006). Kepercayaan merupakan harapan yang dituntut semua orang sesuai dengan janjijanji yang telah diucapkan oleh orang yang bersangkutan, untuk membangun suatu kepercayaan seseorang harus memiliki integritas yang tinggi yang menjadi ukuran bahwa seseorang atau suatu kelompok melakukan segala sesuatunya dengan konsisten, kompeten, jujur, adil dan bertanggung jawab (Sahanggamu, Mananeke, \& Sepang, 2015).

Suatu kepercayaan dibangun oleh pihak-pihak yang belum saling kenal dalam hubungan maupun proses. Dimensi kepercayaan dalam jual beli online sangat berkaitan dengan keyakinan pelanggan. (McKnight, Choudhury, \& Kacmar, 2002). Berikut merupakan indikator-indikator kepercayaan adalah (Salam, 2019):

1) Jujur dalam melakukan pengelolaan situs bisnis online
2) Kompetensi, dimana situs menarik, mudah dan dapat dihandalkan dalam bersaing.

3) Informasi yang diberikan merupakan fakta apa adanya dan dapat dipercaya.

\section{Minat Beli Pelanggan}

Vance Packard (1957) menyatakan bahwa konsumerisme berhubungan dengan strategi dan teknik untuk mendorong pelanggan untuk lebih banyak mengkonsumsi, memenuhi kebutuhan dan keinginan pelanggan. Konsumerisme dipengaruhi oleh aktifitas promosi, iklan, dan penjualan yang agresif. Evolusi orientasi manajemen pemasaran ditandai dengan fase penjualan yang agresif di mana para pemasar mempertimbangkan persediaan stok produk, agresif dalam melakukan kegiatan promosi (Kaufmann \& Panni, 2017).

Minat beli pelanggan adalah tahapan pelanggan dalam memeilih beberapa merek dari beberapa pilihan merek suatu produk. Kemudian dilanjutkan ke tahap pembelian terhadap merek produk yang diinginkan sehingga terjadi transaksi jual beli suatu barang atau jasa dengan berbagai pertimbangan (Islam, 2018). Indikator-indikator dari minat beli dapat dijelaskan sebagai berikut (Adji, 2014):

1) Minat transaksional, yaitu Kecenderungan keinginan seseorang untuk membeli suatu merek produk. 
2) Minat referensial, yaitu Kecenderungan seseorang untuk menyarankan sebuah merek produk kepada orang lain.

3) Minat preferensial, yaitu perilaku seseorang yang memiliki selera pada suatu merek produk tersebut.

4) Minat eksploratif, yaitu perilaku seseorang untuk mencari informasi suatu produk yang diminati.

\section{Penelitian Relevan}

Beberapa penelitian yang sejenis antara lain:

1) Penelitian yang dilakukan oleh Hotlan Siagian dan Edwin Cahyono (2014) yang berjudul, "Analisis Website Quality, Trust, Dan Loyalty Pelanggan Online Shop", menjelaskan, semakin tinggi kualitas situs web belanja online atau online shop, maka pelanggan semakin lebih percaya akan penawaran dan informasu pada situs web tersebut. Setelah pelanggan mengunjungi online shop maka akan memunculkan berbagai penilaian di hati pelanggan atau konsumen, penilaian ini akan menentukan sejauh mana pelanggan dapat mempercayai terhadap online shop tersebut. Kepercayaan berpengaruh terhadap loyalitas, artinya bahwa tinggi rendahnya kepercayaan pelanggan terhadap layanan situs belanja online berpengaruh terhadap loyalitas pelanggan dalam melakukan kunjungan ke suatu situs belanja online (Siagian \& Cahyono, 2014).

2) Penelitian yang dilakukan oleh Resa Nurlaela Anwar, dan Aulia Afifah (2016) yang berjudul, "Pengaruh Kepercayaan Dan Keamanan Pelanggan Terhadap Minat Beli di situs Online (Studi Kasus Pengunjung situs Lazada di Jakarta Timur)", menunjukkan hasil variabel kepercayaan dan keamanan memiliki pengaruh signifikan terhadap minat beli di situs Lazada dimana nilai f-hitung > f-tabel $(9,142>3,09)$. Kepercayaan dan keamanan memiliki pengaruh yang rendah terhadap minat beli di situs Lazada yaitu sebesar 15,9\%. Pengaruh kepercayaan dan keamanan terhadap minat beli di situs Lazada termasuk pengaruh positif yang berarti semakin tinggi kepercayaan dan keamanan maka akan semakin tinggi minat beli dan sebaliknya, semakin rendah kepercayaan dan keamanan maka akan semakin rendah pula minat beli (Anwar \& Afifah, 2018).

\section{Tujuan Penelitian}

Dari hal-hal yang telah disampaikan di atas maka tujuan penelitiannya dapat disampaikan sebagai berikut:

1) Untuk mengetahui kualitas website Bukalapak di wilayah Kota Tangerang.

2) Untuk mengetahui kualitas pelayanan Bukalapak di wilayah Kota Tangerang. 
3) Untuk mengetahui kepercayaan pelanggan Bukalapak di wilayah Kota Tangerang.

4) Untuk mengetahui pengaruh kualitas website terhadap minat beli pelanggan Bukalapak di wilayah Kota Tangerang.

5) Untuk mengetahui pengaruh kualitas pelayanan terhadap minat beli pelanggan Bukalapak di wilayah Kota Tangerang.

6) Untuk mengetahui pengaruh kepercayaan pelanggan terhadap minat beli konsumen Bukalapak di wilayah Kota Tangerang.

7) Tingkat pelayanan dan tingkat kepercayaan pelanggan dapat dipengaruhi oleh kualitas websites yang terlihat dari para pelanggan yang melakukan pembelian Bukalapak di wilayah Kota Tangerang.

\section{B. Metode Penelitian}

\section{Metode Penelitian}

Penelitian dilakukan menggunakan metode penelitian kuantitatif asosiatif kausal, dengan teknik survey menggunakan kuesioner. Pada penelitian ini, peneliti mencari hubungan pengaruh sebab-akibat.

\section{Tempat dan Waktu Penelitian}

Penelitian dilaksanakan pada bulan November 2019 pada responden di Kota Tangerang.

\section{Populasi dan Sampel}

Untuk melakukan penelitian ini menggunakan sample 100 orang. Dimana kesemuanya merupakan penduduk yang bertempat tinggal di kota Tangerang yang pernah melakukan pembelian melalui situs online Bukalapak

\section{Teknik Pengumpulan Data}

Penelitian menggunakan dua jenis data sekunder dan data primer. Data sekunder diambil dari data pusat statistik Kota Tangerang, beberapa penelitian terdahulu, data dari rujukan elektronik serta, referensi pustaka. Data primer diperoleh dari responden melalui pengisian kuisioner.

\section{Teknik Pengambilan Sampel}

Teknik pengambilan sampel Nonprobability Sampling dengan kategori Judgmental Sampling, yaitu hanya pelanggan yang pernah berbelanja di situs online Bukalapak.

\section{Kerangka Pemikiran}

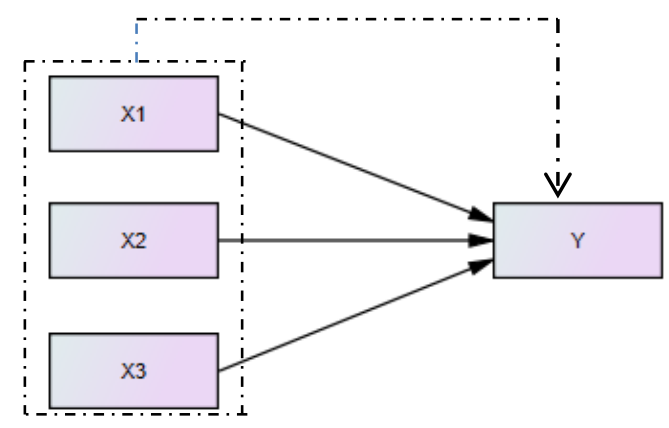

X1: Kualitas Website

X2: Kualitas Pelayanan

X3: Kepercayaan Pelanggan

Y: Minat Beli 


\section{Kisi-kisi Instrumen Penelitian}

Berdasarkan kajian teori, maka kisikisi penyusunan instrumen dari penelitian sebagai berikut:

\begin{tabular}{|c|c|c|}
\hline \multicolumn{3}{|c|}{ Tabel 3 Kisi-kisi Instrumen Penelitian } \\
\hline No & Variabel & Indikator \\
\hline \multirow{5}{*}{1.} & \multirow{5}{*}{ Website } & Keamanan \\
\hline & & Kenyamanan \\
\hline & & Informasi \\
\hline & & Kemudahan \\
\hline & & $\begin{array}{l}\text { Kualitas } \\
\text { Pelayanan }\end{array}$ \\
\hline \multirow[t]{5}{*}{2.} & \multirow[t]{5}{*}{ Pelayanan } & $\begin{array}{l}\text { Tangible (bukti } \\
\text { langsung) }\end{array}$ \\
\hline & & $\begin{array}{l}\text { Realibility } \\
\text { (kehandalan) }\end{array}$ \\
\hline & & $\begin{array}{l}\text { Responsiveness } \\
\text { (daya tanggap) }\end{array}$ \\
\hline & & $\begin{array}{l}\text { Assurance } \\
\text { (jaminan) }\end{array}$ \\
\hline & & Empathy (empati) \\
\hline \multirow[t]{3}{*}{3.} & \multirow{3}{*}{$\begin{array}{l}\text { Kepercayaan } \\
\text { Pelanggan }\end{array}$} & Kejujuran \\
\hline & & Kompetensi \\
\hline & & Informasi \\
\hline \multirow[t]{4}{*}{4.} & \multirow[t]{4}{*}{ Minat Beli } & $\begin{array}{l}\text { Minat } \\
\text { transaksional }\end{array}$ \\
\hline & & Minat referensial \\
\hline & & Minat preferensial \\
\hline & & Minta eksploratif \\
\hline
\end{tabular}

\section{Teknis Analisis Data}

Teknis analisis data menggunakan statistik deskriptif dan statistik inferensial dengan regresi ganda menggunakan program software SPSS.

Statistik deskriptif untuk menggambarkan data. Fokus statistik deskriptif merupakan penyajian sebagian atau seluruh data (pengamatan). Statistik inferensial memberikan kesimpulan tentang suatu populasi berdasar informasi yang terkandung di dalam sampel dari populasi tersebut. Statistik inferensial menarik kesimpulan berdasar data-data dan fakta yang didapat (Prastowo, 2020).

\section{Hasil Penelitian dan Pembahasan}

\begin{tabular}{|l|r|r|r|r|}
\hline & TOT X1 & TOT X2 & TOT X3 & TOT Y1 \\
\hline N Valid & 100 & 100 & 100 & 100 \\
Missing & 0 & 0 & 0 & 0 \\
\hline Mean & 21.1100 & 38.6700 & 14.3800 & 13.8100 \\
\hline Std. Error of Mean & .29709 & .53523 & .24691 & .26196 \\
\hline Median & 21.5000 & 39.0000 & 14.0000 & 14.0000 \\
\hline Mode & 23.00 & 44.00 & 16.00 & 12.00 \\
\hline Std. Deviation & 2.97089 & 5.35234 & 2.46912 & 2.61964 \\
\hline Variance & 8.826 & 28.648 & 6.097 & 6.863 \\
\hline Skewness & -.192 & .256 & -.334 & -.229 \\
\hline Std. Error of Skewness & .241 & .241 & .241 & .241 \\
\hline Kurtosis & .131 & .270 & .398 & .509 \\
\hline Std. Error of Kurtosis & .478 & .478 & .478 & .478 \\
\hline Range & 16.00 & 31.00 & 13.00 & 14.00 \\
\hline Minimum & 14.00 & 24.00 & 7.00 & 6.00 \\
\hline Maximum & 30.00 & 55.00 & 20.00 & 20.00 \\
\hline Percentiles & 19.0000 & 34.0000 & 12.2500 & 12.0000 \\
& 21.5000 & 39.0000 & 14.0000 & 14.0000 \\
\hline & 23.0000 & 43.0000 & 16.0000 & 16.0000 \\
\hline
\end{tabular}

Dari hasil olah data penelitian dengan statistik deskriptif, menunjukkan dari 100 data responden yang valid pada tingkat kepercayaan 95\%, nilai mean (ratarata) dari kualitas website Bukalapak sebesar 21,1100, nilai rata-rata dari kualitas pelayanan 38,6700, nilai rata-rata dari kepercayaan pelanggan 14,3800 , dan nilai rata-rata dari minat beli pelanggan Bukalapak sebesar 13,8100. Dari 100 responden, $50 \%$ responden berpendapat bahwa kualitas website Bukalapak 21,5000, kualitas pelayanan 39,0000, kepercayaan pelanggan 14,0000 , dan minat beli pelanggan sebesar 14,0000. Frekuensi nilai dari pendapat responden, banyak memberikan pendapat kualitas website 23,00, kualitas pelayanan 44,00, 
kepercayaan pelanggan 16,00 , minat beli pelanggan 12,00 .

Dari uji linearitas pada arah regresi Y*X1 (Minat beli terhadap kualitas website) sebesar 0,214>0,05, yang artinya bahwa arah bersifat linear, maka $\mathrm{H}_{0}$ ditolak dan $\mathrm{H}_{1}$ diterima. Dari uji linearitas pada arah regresi $\mathrm{Y}^{*} \mathrm{X} 2$ (Minat beli terhadap kualitas pelayanan) sebesar 0,448 $>0,05$, yang artinya bahwa arah bersifat linear, maka $\mathrm{H}_{0}$ ditolak dan $\mathrm{H}_{1}$ diterima. Dari uji linearitas pada arah regresi $\mathrm{Y}^{*} \mathrm{X} 3$ (Minat beli terhadap Kepercayaan pelanggan) sebesar $0,095>0,05$, yang artinya bahwa arah bersifat linear, maka $\mathrm{H}_{0}$ ditolak dan $\mathrm{H}_{1}$ diterima.

\section{Descriptive Statistics}

\begin{tabular}{|l|l|r|r|}
\hline & Mean & Std. Deviation & N \\
\hline TOT_Y1 & 13.8100 & 2.61964 & 100 \\
TOT_X1 & 21.1100 & 2.97089 & 100 \\
TOT_X2 & 38.6700 & 5.35234 & 100 \\
TOT_X3 & 14.3800 & 2.46912 & 100 \\
\hline
\end{tabular}

Nilai rata-rata dan standar deviasi:

$Y=13,8100$ dan 2,61964;

$X 1=21,1100$ dan 2,97089;

$\mathrm{X} 2=38,6700$ dan 5,35234;

$\mathrm{X} 3=14,3800$ dan 2,46912.

Pada hasil tidak terdapat data yang outlier atau data yang aneh.

\begin{tabular}{|c|c|c|c|c|c|}
\hline & & $\begin{array}{c}\mathrm{TOT}_{-} \\
\mathrm{Y} 1\end{array}$ & $\begin{array}{c}\mathrm{TOT}_{-} \\
\mathrm{X} 1\end{array}$ & $\begin{array}{c}\mathrm{TOT}_{-} \\
\mathrm{X} 2\end{array}$ & $\begin{array}{c}\text { TOT_ } \\
\text { X3 }\end{array}$ \\
\hline \multirow{2}{*}{$\begin{array}{l}\text { Pearson } \\
\text { Correlatio }\end{array}$} & TOT_Y1 & 1.000 & .653 & .624 & .528 \\
\hline & TOT_X1 & .653 & 1.000 & .691 & .606 \\
\hline
\end{tabular}

\begin{tabular}{|lr|r|r|r|r|}
\hline $\mathrm{n}$ & TOT_X2 & .624 & .691 & 1.000 & .529 \\
& TOT_X3 & .528 & .606 & .529 & 1.000 \\
\hline Sig. (1- & TOT_Y1 &. & .000 & .000 & .000 \\
tailed) & TOT_X1 & .000 &. & .000 & .000 \\
& TOT_X2 & .000 & .000 &. & .000 \\
& TOT_X3 & .000 & .000 & .000 &. \\
\hline $\mathrm{N}$ & TOT_Y1 & 100 & 100 & 100 & 100 \\
& TOT_X1 & 100 & 100 & 100 & 100 \\
& TOT_X2 & 100 & 100 & 100 & 100 \\
& TOT_X3 & 100 & 100 & 100 & 100 \\
\hline
\end{tabular}

Variabel Y signifikan pada korelasi dengan $\mathrm{X} 1, \mathrm{X} 2$, dan $\mathrm{X} 3$ dapat dilihat dari angka Sig. (1-tailed), Y terhadap X1, X2, X3 yaitu dengan nilai Sig. 0,000 0,05, artinya $\mathrm{H}_{0}$ ditolak dan $\mathrm{H}_{1}$ diterima, maka koefisien korelasi signifikan secara statistik.

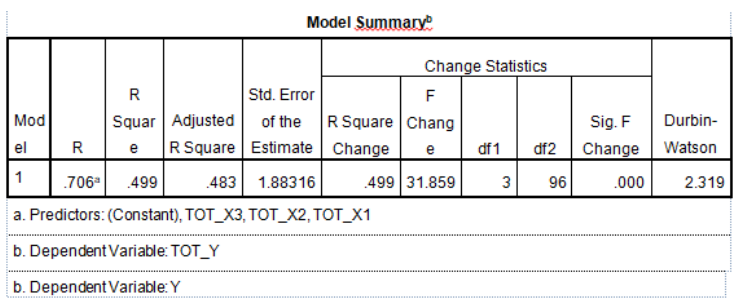

Pada uji signifikansi koefisien korelasi ganda, ditunjukkan pada output SPSS Model Summary, bahwa koefisien determinasi $\mathrm{R}^{2}=0,499, \mathrm{~F}_{\text {hit }}=31,859, p$ value $=0,000<0,005$ atau $\mathrm{H}_{0}$ ditolak, artinya $49,9 \%$ dari variasi yang terjadi pada variabel Minat Beli Pelanggan (Y), disebabkan oleh pengaruh variabel kualitas website, kualitas pelayanan, dan kepercayaan pelanggan secara bersamasama, sedangkan sisanya $50,1 \%$ disebabkan oleh pengaruh variabelvariabel lain yang tidak diteliti atau sebagai residu. Jadi Pengaruh variabel 
kualitas website, kualitas pelayanan, dan kepercayaan pelanggan terhadap minat beli pelanggan sebesar 0,499 atau 49,9\%.

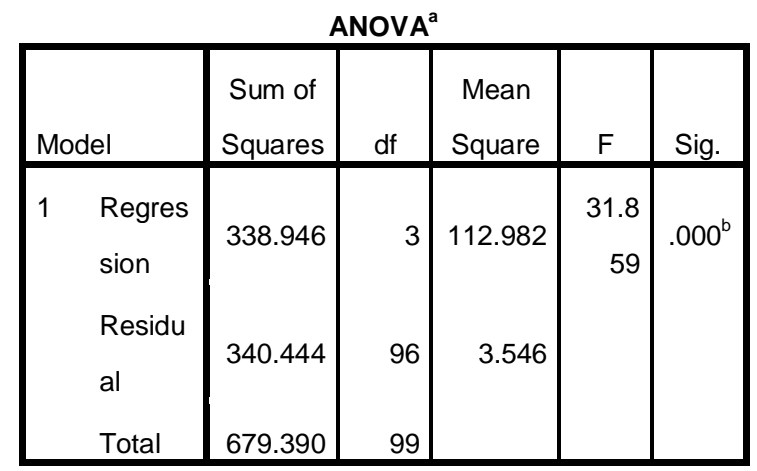

a. Dependent Variable: TOT_Y

b. Predictors: (Constant), TOT_X3, TOT_X2, TOT_X1

Pada Uji Signifikansi Persamaan Regresi Ganda yang ditunjukkan pada tabel Anova, Hasil analisis nilai $F_{h i t}=$ 31,859 , dengan nilai signifikansi $0,000<$ $0,05, \mathrm{H}_{0}$ ditolak, artinya persamaan regresi signifikan, sehingga dapat digunakan untuk membuat dasar prediksi. Maka variabel Y (minat beli) dipengaruhi oleh prediktor X1, X2, dan X3, atau Kualitas Website (X1), Kualitas Pelayanan (X2), dan Kepercayaan pelanggan (X3), secara simultan berpengaruh terhadap Minat Beli pelanggan (Y).

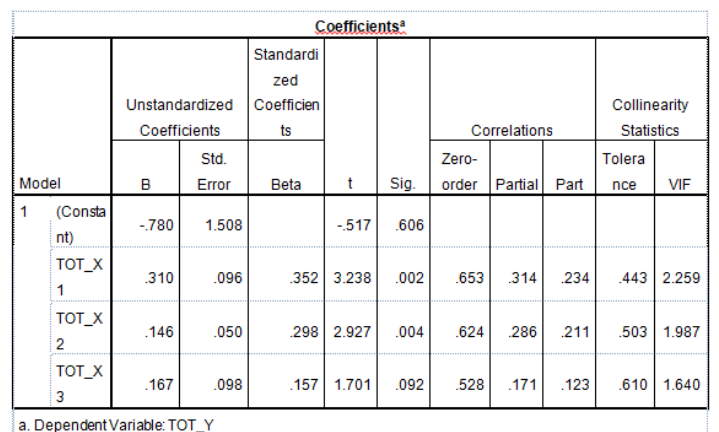

Pada Persamaan Linear Ganda dan Uji Signifikansi Koefisien Persamaan Regresi ditunjukkan pada output SPSS tabel Coefficient, Persamaan regresi $\mathrm{Y}=$ $0,780+0,310 \mathrm{X} 1+0,146 \mathrm{X} 2+0,167 \mathrm{X} 3$, artinya rata-rata skor kriterium Minat beli (Y) diperkirakan akan mengalami perubahan sebesar 0,310 untuk setiap unit perubahan pada Kualitas Website (X1), berubah sebesar 0,146 untuk setiap unit perubahan pada Kualitas Pelayanan (X2), berubah sebesar 0,167 untuk setiap unit perubahan pada Kepercayaaan pelanggan (X3). Nilai statistik untuk variabel X1 yaitu $\mathrm{t}_{\text {hit }}=3,238$ dan $p$-value $=0,002<$ $0,05 \mathrm{H}_{0}$ ditolak, yang artinya Kualitas Website (X1) berpengaruh positif terhadap Minat Beli pelanggan. Nilai statistik untuk variabel X2 yaitu $\mathrm{t}_{\text {hit }}=2,927$ dengan $p$ value $=0,004<0,05$ atau $\mathrm{H}_{0}$ ditolak, artinya Kualitas Pelayanan berpengaruh positif terhadap Minat Beli pelanggan (Y). Nilai statistik untuk variabel $\mathrm{X} 3$ yaitu $\mathrm{t}_{\text {hit }}=1,701$ dengan $p$-value $=$ 0,092>0,05 atau $\mathrm{H}_{0}$ diterima, artinya Kepercayaan pelanggan (X3) tidak berpengaruh positif terhadap Minat Beli pelanggan $(\mathrm{Y})$.

$$
\text { Model regresi terjadi }
$$

multikolinearitas atau tidak, dapat dilihat dengan output SPSS pada tabel Coefficients $^{a}$ yaitu:

Nilai Tolerance variabel X1 0,443 > 0,10. 
Nilai Tolerance variabel X2 0,503>0,10.

Nilai Tolerance variabel X3 0,610>0,10.

Nilai VIF variabel X1 2,259 < 10,00

Nilai VIF variabel X2 1,987 < 10,00

Nilai VIF variabel X3 1,640 < 10,00

Sehingga dapat disimpulkan bahwa model regresi ini tidak terjadi multikolinearitas.

D. KESIMPULAN, IMPLIKASI, DAN

\section{SARAN}

\section{Kesimpulan}

Berdasarkan hasil analisis SPSS, penelitian berjudul "Analisis Pengaruh Kualitas Website, Kualitas Pelayanan, Dan Kepercayaan Pelanggan Terhadap Minat Beli Pelanggan Di Situs Belanja Online Bukalapak", menghasilkan persamaan struktural yang dapat menjelaskan pengaruh masing-masing variabel independen terhadap variabel dependen.

Adapun persamaan yang dihasilkan sebagai berikut:

Persamaan regresi $\mathrm{Y}=-0,780+0,310 \mathrm{X} 1$ $+0,146 \mathrm{X} 2+0,167 \mathrm{X} 3$,

Pengujian hipotesis secara statistik terhadap pengaruh masing-masing variabel independen terhadap variabel dependen, menghasilkan kesimpulan sebagai berikut:

1. Berdasarkan persamaan struktural yang dihasilkan dari penelitian ini, dapat disimpulkan bahwa variabel kualitas website bukalapak berpengaruh paling dominan terhadap minat beli pelanggan bukalapak, ini ditunjukkan dengan nilai koefisien sebesar 0,310, dimana nilai ini merupakan nilai terbesar dibandingkan dengan koefisien dari variabel kualitas pelayanan (sebesar 0,146), maupun variabel kepercayaan pelanggan (sebesar 0,167). Atau dapat disimpulkan rata-rata skor kriterium Minat beli (Y) diperkirakan akan mengalami perubahan sebesar 0,310 untuk setiap unit perubahan pada Kualitas Website (X1), berubah sebesar 0,146 untuk setiap unit perubahan pada Kualitas Pelayanan (X2), berubah sebesar 0,167 untuk setiap unit perubahan pada Kepercayaaan pelanggan (X3).

2. Kualitas Website Bukalapak (X1) berpengaruh positif terhadap Minat Beli pelanggan Bukalapak (Y). Kesimpulan ini berdasarkan bahwa nilai statistik untuk variabel $X 1$ yaitu $t_{\text {hit }}=3,238$ dan p-value $=0,002<0,05 \mathrm{H}_{0}$ ditolak dan $\mathrm{H}_{1}$ diterima. Artinya Minat beli pelanggan bukalapak dipengaruhi oleh kualitas website bukalapak. Kualitas website bukalapak yang baik akan meningkatkan minat beli pelanggan bukalapak.

3. Kualitas Pelayanan bukalapak (X2) berpengaruh positif terhadap Minat Beli pelanggan bukalapak (Y). Kesimpulan ini berdasarkan bahwa nilai statistik untuk variabel $\mathrm{X} 2$ yaitu $\mathrm{t}_{\text {hit }}=2,927$ 
dengan $p$-value $=0,004<0,05$ atau $\mathrm{H}_{0}$ ditolak dan $\mathrm{H}_{2}$ diterima. Artinya Minat beli pelanggan bukalapak dipengaruhi oleh kualitas pelayanan bukalapak. Kualitas pelayanan bukalapak yang baik akan meningkatkan minat beli pelanggan bukalapak.

4. Kepercayaan pelanggan bukalapak (X3) tidak berpengaruh positif terhadap Minat Beli pelanggan (Y). Kesimpulan ini berdasarkan bahwa nilai statistik untuk variabel $\mathrm{X} 3$ yaitu $\mathrm{t}_{\text {hit }}=1,701$ dengan $p$-value $=0,092>0,05$ atau $\mathrm{H}_{0}$ diterima dan $\mathrm{H}_{3}$ ditolak. Artinya Minat beli pelanggan bukalapak tidak dipengaruhi oleh kepercayaan pelanggan bukalapak.

5. Minat beli pelanggan bukalapak (Y) dipengaruhi secara signifikan oleh variabel Kualitas Website (X1), Kualitas Pelayanan (X2), dan Kepercayaan pelanggan (X3), secara simultan. Kesimpulan ini didasarkan pada uji signifikansi persamaan regresi ganda yang ditunjukkan pada tabel Anova, dengan hasil analisis nilai $\mathrm{F}_{\mathrm{hit}}=$ 31,859 , dengan nilai signifikansi 0,000 $<0,05$, artinya $\mathrm{H}_{0}$ ditolak

6. 49,9\% dari variasi yang terjadi pada variabel minat beli pelanggan bukalapak (Y), disebabkan oleh pengaruh variabel kualitas website, kualitas pelayanan, dan kepercayaan pelanggan secara bersama-sama, sedangkan sisanya $50,1 \%$ disebabkan oleh pengaruh variabel-variabel lain yang tidak diteliti atau sebagai residu. Kesimpulan ini didasarkan pada uji signifikansi koefisien korelasi ganda, yang ditunjukkan pada output SPSS Model Summary, bahwa koefisien determinasi $\mathrm{R}^{2}=0,499, \mathrm{~F}_{\text {hit }}=31,859$, $p$-value $=0,000<0,005$ atau $\mathrm{H}_{0}$ ditolak.

\section{Implikasi Kebijakan}

Hasil penelitian memiliki implikasi yang dapat digunakan sebagai pertimbangan oleh manajemen perusahaan di dalam menentukan skala prioritas kebijakan. Adapun skala prioritas kebijakan berdasarkan hasil penelitian adalah sebagai berikut:

1) Menjaga dan meningkatkan kualitas website bukalapak, yang mendukung peningkatan minat beli pelanggan bukalapak.

2) Menjaga dan meningkatkan kualitas pelayanan bukalapak, yang mendukung peningkatan minat beli pelanggan bukalapak.

\section{Saran}

Saran-saran yang dapat menjadi pertimbangan untuk meningkatkan minat beli pelanggan di situs belanja online bukalapak adalah sebagai berikut: 
1. Bukalapak dapat memberikan jaminan keamanan akan privasi kepada pelanggan.

2. Bukalapak dapat memberikan kenyamanan secara emosional, memiliki kreatifitas desain yang menarik.

3. Bukalapak sebaiknya memberikan informasi yang akurat, bermanfaat, dan berkualitas terhadap produk-produk yang ditawarkan.

4. Bukalapak sebaiknya memberikan informasi yang mudah dipahami, mudah diproses dan cepat dalam proses.

\section{E. DAFTAR PUSTAKA}

Adji, J. (2014). Pengaruh Satisfaction dan Trust Terhadap Minat Pembelian di Starbucks The Square Surabaya. Jurnal Strategi Pemasaran, 2(1), 1-10. Retrieved from http://publication.petra.ac.id/index.php/ manajemenpemasaran/article/view/1394

Anwar, R. N., \& Afifah, A. (2018). Kepercayaan dan Keamanan Konsumen terhadap Minat Beli di situs Online (Studi Kasus pengunjung situs Lazada di Jakarta Timur). Jurnal Manajemen, 9(1), 46. https://doi.org/10.32832/jmuika.v9i1.1316

Arie Prayoga. (2018). Analisis Perbandingan Kualitas Pelayanan Pada Indomaret dan Alfamart Di Candi Gebang, Sleman , daerah Istimewa Yogyakarta. Retrieved from UII website: https://dspace.uii.ac.id/handle/1234567 89/12164
5. Bukalapak memberikan pelayanan kepada pelanggan secara online dengan lengkap.

6. Bukalapak sebaiknya dapat merespon setiap keluhan atau komplain dari setiap pelanggan.

7. Bukalapak memberikan empati kepada setiap pelanggan yang loyal baik dengan memberikan berbagai program promo atau kegiatan sosial untuk berpartisipasi dalam kesejahteraan pelanggan.

8. Bukalapak dapat memberikan jaminan keamanan akan produk yang dijual/ pasarkan.

Bekti, H. (2015). Mahir membuat website dengan adobe dreamweaver CS6, CSS, dan JQUERY. In Adobe Dreamweaver CS6, CSS, dan Jquery.

Büttner, O. B., \& Göritz, A. S. (2008). Perceived trustworthiness of online shops. In Journal of Consumer Behaviour (Vol. https://doi.org/10.1002/cb.235

Fox, V. (2010). Marketing in the Age of Google: Your Online Strategy Is Your Business Strategy. Retrieved from http://books.google.com/books?id=We UadFeW498C\&printsec $=$ frontcover $\% 5$ Cnpapers2://publication/uuid/F992994F -57DD-4D5C-8A54-52967C65E906

Ghani, R. (2018). Peran Perantara eKepuasan dan e-Kepercayaan Pada Pengembangan e-Loyalitas Dalam Konteks Bisnis Online Pada Pembelanja Online Wanita. Retrieved from UII website: https://dspace.uii.ac.id/handle/1234567 
$89 / 11089$

Gregg, D. G., \& Walczak, S. (2010). The relationship between website quality, trust and price premiums at online auctions. In Electronic Commerce Research (Vol. 10). https://doi.org/10.1007/s10660-0109044-2

Gutavsson, M. \& J. A. (2006). Consumer Trust in E-Commerce Gutavsson, M. \& Johansson A. - Google Cendekia. Retrieved from https://scholar.google.co.id/scholar?hl=i $\mathrm{d} \&$ as_sdt $=0 \% 2 \mathrm{C} 5 \& \mathrm{q}=$ Consumer+Trust + in + E-

Commerce+Gutavsson\%2C + M. $+\% 26+$ Johansson+A.\&btnG=

Hidayat, T. (2008). Panduan Membuat Sistem informasi penjualan online dengan OSCommerce. Retrieved from https://books.google.com/books?hl=id\& $\mathrm{lr}=\& \mathrm{id}=\mathrm{ybIPPdxW5A0C \& oi=fnd \& pg=}$ PR5\&dq=related:idWEwWavpFQJ:sch olar.google.com/\&ots=1xiX5MlINP\&si $\mathrm{g}=$ tLlUqYe63TsRAbX10i0b2IW0ShY

Islam, R. H. (2018). Pengaruh Bauran Promosi Dan Kualitas Pelayanan Terhadap Minat Mencuci Ulang Pada Sneaklin 3rd Workshop Buah Batu No.197 Bandung. Retrieved from https://repository.widyatama.ac.id/xmlu i/handle/123456789/10128

Jackson, S. (2009). Cult of Analytics: Driving online marketing strategies using web analytics. In Cult of Analytics: Driving online marketing strategies using web analytics. https://doi.org/10.4324/9780080885179

Kaufmann, H. R., \& Panni, M. F. A. K. (2017). Socio-economic perspectives on consumer engagement and buying behavior. https://doi.org/10.4018/978-15225-2139-6
Kim, H., \& Niehm, L. S. (2009). The Impact of Website Quality on Information Quality, Value, and Loyalty Intentions in Apparel Retailing. In Journal of Interactive Marketing (Vol. 23). https://doi.org/10.1016/j.intmar.2009.04 .009

Laily, A. N. (2019). Laily: Pengaruh online experience dan online concerns... Google Cendekia. Retrieved from https://scholar.google.com/scholar?hl=i d\&as_sdt=0\%2C5\&q=http $\% 3 \mathrm{~A} \% 2 \mathrm{~F} \% 2$ Frepository.wima.ac.id\%2F17395\%2F3 $\% 2 \mathrm{FBAB} \% 25201 . p d f \& b t n G=\# d=g s \_c i$ $\mathrm{t} \& \mathrm{u}=\% 2 \mathrm{Fscholar} \% 3 \mathrm{Fq} \% 3 \mathrm{Dinfo} \% 3 \mathrm{AQ}-$ ClK3n9tEEJ\%3Ascholar.google.com\% 2F\%26output\%3Dcite\%26scirp\%3D0\% 26hl\%3Did

McKnight, D. H., Choudhury, V., \& Kacmar, C. (2002). Developing and validating trust measures for ecommerce: An integrative typology. Information Systems Research, 13(3), 334-359.

https://doi.org/10.1287/isre.13.3.334.81

Roy Franedya. (2019). Ini Toko Online yang Paling Sering Dikunjungi Orang RI. Retrieved from https://www.cnbcindonesia.com/tech/20 190516203654-37-73077/ini-tokoonline-yang-paling-sering-dikunjungiorang-ri

Sahanggamu, S., Mananeke, L., \& Sepang, J. (2015). Analisis Kualitas Layanan, Servicescape Dan Kepercayaan terhadap Kepuasan Nasabah Pada PT. Bank Sinar Mas Bitung. Jurnal EMBA: Jurnal Riset Ekonomi, Manajemen, Bisnis Dan Akuntansi, 3(1). https://doi.org/10.35794/EMBA.V3I1.7 868

Salam, F. R. (2019). Pengaruh Kepercayaan Dan Pelayanan Karyawan Terhadap Tingkat Kepuasan Pelanggan Pada Pdam Pdam Di Kecamatan Secanggang 
D. Volume 25, Nomor 2, Januari 2020

P-ISSN: 1411 - 545X | E ISSN: 2715-1662

Kabupaten Langkat. - Repository UIN Sumatera Utara. Retrieved January 27, 2020, from

http://repository.uinsu.ac.id/7831/

Satria, A. A. (2017). Pengaruh Harga, Promosi, Dan Kualitas Produk Terhadap Minat Beli Konsumen Pada Perusahaan A-36. In PERFORMA: Jurnal Manajemen dan Start-Up Bisnis (Vol. 2).

Siagian, H., \& Cahyono, E. (2014). Analisis Website Quality, Trust Dan Loyalty Pelanggan Online Shop. Jurnal Manajemen Pemasaran, 8(2). https://doi.org/10.9744/pemasaran.8.2.5 5-61 